\title{
Role of Protein Phosphatases in Estrogen-Mediated Neuroprotection
}

\author{
Kun Don Yi, Jaegwon Chung, Priscilla Pang, and James W. Simpkins \\ Department of Pharmacology and Neuroscience, University of North Texas Health Science Center, Fort Worth, Texas 76107
}

The signaling pathways that mediate neurodegeneration are complex and involve a balance between phosphorylation and dephosphorylation of signaling and structural proteins. We have shown previously that $17 \beta$-estradiol and its analogs are potent neuroprotectants. The purpose of this study was to delineate the role of protein phosphatases (PPs) in estrogen neuroprotection against oxidative stress and excitotoxicity. HT-22 cells, C6-glioma cells, and primary rat cortical neurons were exposed to the nonspecific serine/threonine protein phosphatase inhibitors okadaic acid and calyculin A at various concentrations in the presence or absence of $17 \beta$-estradiol and/or glutamate. Okadaic acid and calyculin A caused a dose-dependent decrease in cell viability in HT-22, C6-glioma, and primary rat cortical neurons. $17 \beta$-Estradiol did not show protection against neurotoxic concentrations of either okadaic acid or calyculin A in these cells. In the absence of these serine/threonine protein phosphatase inhibitors, $17 \beta$-estradiol attenuated glutamate toxicity. However, in the presence of effective concentrations of these protein phosphatase inhibitors, $17 \beta$-estradiol protection against glutamate toxicity was lost. Furthermore, glutamate treatment in HT-22 cells and primary rat cortical neurons caused a 50\% decrease in levels of PP1, PP2A, and PP2B protein, whereas coadministration of $17 \beta$-estradiol with glutamate prevented the decrease in PP1, PP2A, and PP2B levels. These results suggest that $17 \beta$-estradiol may protect cells against glutamate-induced oxidative stress and excitotoxicity by activating a combination of protein phosphatases.

Key words: estrogen; neuroprotection; phosphatases; neurotoxicity; glutamate; neuronal death

\section{Introduction}

Protein phosphatases (PPs) are essential in directing signaling toward neuroprotection or neurodegeneration. PPs are important regulators of neurodegenerative disease processes such as Alzheimer's disease (AD), in which oxidative stress is an important contributing factor (Perry et al., 2002). Additionally, PPs are important regulators of tau phosphorylation. In neurons, okadaic acid causes hyperphosphorylation of tau, synapse modification, microtubule destabilization, and apoptosis (Harris et al., 1993; Saito et al., 1995; Fernandez-Sanchez et al., 1996; Garver et al., 1996; Malchiodi-Albedi et al., 1997; Merrick et al., 1997). PP1, PP2A, and PP2B (calcineurin) expression and/or activity have been found to be reduced greatly in $\mathrm{AD}$ brains compared with aged-matched control brains (Gong et al., 1993; Lian et al., 2001; Sontag et al., 2004).

The pathological mechanisms that are activated during neurodegenerative diseases, including oxidative stress, excitotoxicity, inflammatory responses, mitochondrial dysfunction, and apoptosis, are antagonized by estrogens (Green et al., 1996, 1997a,b, 1998; Gridley et al., 1997). In vitro studies indicate that estrogens increase the viability and differentiation of primary cultures from different neuronal populations from the hypothalamus, amyg-

\footnotetext{
Received April 6, 2005; revised June 17, 2005; accepted June 22, 2005.

This work was supported by National Institutes of Health Grants AG10485 and AG22550.

Correspondence should be addressed to Dr. James W. Simpkins, University of North Texas Health Science Center,

3500 Camp Bowie Boulevard, Fort Worth, TX 76107. E-mail: jsimpkin@hsc.unt.edu.

DOI:10.1523/JNEUROSCI.1328-05.2005

Copyright $\odot 2005$ Society for Neuroscience $\quad$ 0270-6474/05/257191-08\$15.00/0
}

dala, neocortex, or hippocampus. Numerous in vivo studies have also demonstrated the neuroprotective effects of estrogens in a variety of animal stroke models, including transient and permanent middle cerebral artery occlusion (Simpkins et al., 1997; Alkayed et al., 1998; Dubal et al., 1998), global forebrain ischemia (Sudo et al., 1997), photothrombotic focal ischemia (Fukuda et al., 2000), glutamate-induced focal cerebral ischemia (Mendelowitsch et al., 2001), and subarachnoid hemorrhage (Yang et al., 2001).

Excitotoxicity and oxidative stress are known to disrupt intracellular signaling by persistently activating several phosphorylation-dependent pathways. Insult-induced persistent activation of ERK1/2 (extracellular signal-regulated kinase 1/2) has been shown to play a role in oxidative stress-induced cell death in HT-22 and primary neurons (Stanciu et al., 2000). Persistent activation of protein kinase C (PKC) associated with ethanol-induced neurotoxicity has also been shown (Jung et al., 2005). Also, in models of stroke, brain trauma, and neurodegenerative diseases, the detrimental effects of persistent activation of ERK1/2 during oxidative as well as excitotoxic neuronal injury have been documented (Slevin et al., 2000; Stanciu et al., 2000; Zhu et al., 2002a,b; Ferrer et al., 2003; Harper and Wilkie, 2003). Estrogens have been shown to block the persistent activation of both ERK and PKC (Watters et al., 1997; Singh et al., 1999, 2000; Bi et al., 2000; Kuroki et al., 2000; Jung et al., 2005)

The role of PPs in estrogen-mediated neuroprotection against excitotoxicity and oxidative stress-induced cell death was investigated. In this study, we show that inhibition of PPs prevents the 
$17 \beta$-estradiol-mediated neuroprotection against oxidative and excitotoxic stress. Inhibition of PPs is neurotoxic, and $17 \beta$ estradiol is ineffective in protecting against this toxicity. Oxidative stress and excitotoxicity cause a decrease in PP content, which is antagonized by $17 \beta$-estradiol. In the presence of okadaic acid, the $17 \beta$-estradiol-mediated stabilization of PP levels is abrogated. Collectively, these data implicate a role for PPs in estrogen-mediated neuroprotection.

\section{Materials and Methods}

Chemicals. $17 \beta$-Estradiol was purchased from Steraloids (Wilton, $\mathrm{NH}$ ) and dissolved in dimethyl sulfoxide (DMSO) at a concentration of $10 \mathrm{mM}$ and diluted to appropriate concentration in culture media. Calcein AM was purchased from Molecular Probes (Eugene, OR). Okadaic acid, L-glutamate, and DMSO were purchased from Sigma (Paris, KY). Calyculin A was purchased from Calbiochem (La Jolla, CA). Anti-PP1, antiPP2A, and anti-PP2B were purchased from Santa Cruz Biotechnology (Santa Cruz, CA).

Cell culture. HT-22 and C6-glioma cells were cultured in DMEM supplemented with 10\% charcoal-stripped FBS (HyClone, Logan, UT) and gentamicin $(50 \mu \mathrm{g} / \mathrm{ml})$ at $37^{\circ} \mathrm{C}$ in an atmosphere containing $5 \% \mathrm{CO}_{2}$ and 95\% air. HT-22 cells were obtained from David Schubert (Salk Institute, San Diego, CA). C6-glioma cells were obtained from American Type Tissue Collection (Rockville, MD). HT-22 and C6-glioma cultures were maintained at 50 and $100 \%$ confluency, respectively, in monolayers in plastic $75 \mathrm{~cm}^{2}$ flasks.

Culture of primary cortical neurons. Cerebral cortex rat embryo (18 d) were dissected and harvested in preparation medium (DMEM; $4.5 \mathrm{~g} / \mathrm{L}$ glucose, $100 \mathrm{U} / \mathrm{ml}$ penicillin, $100 \mu \mathrm{g} / \mathrm{ml}$ streptomycin). The cortical tissue was treated with trypsin. The tissue was washed three times using washing medium (HBSS; $4.5 \mathrm{~g} / \mathrm{L}$ glucose, $100 \mathrm{U} / \mathrm{ml}$ penicillin, $100 \mu \mathrm{g} / \mathrm{ml}$ streptomycin), and individual cells were isolated by mechanical trituration using three different sizes of fire-polished Pasteur pipettes. The cells were harvested in seeding medium (DMEM; $4.5 \mathrm{~g} / \mathrm{L}$ glucose, $100 \mathrm{U} / \mathrm{ml}$ penicillin, $100 \mu \mathrm{g} / \mathrm{ml}$ streptomycin, $2 \mathrm{~mm}$ glutamine, $19 \%$ horse serum) and filtered through $40 \mu \mathrm{m}$ filter. The cerebral cortical cells were seeded in poly-L-lysine-treated $100 \mathrm{~mm}$ dishes and 96-well plates at a density of 100,000 cells $/ \mathrm{ml}$ and 25,000 cells per well, respectively. The cells were incubated in neurobasal medium (DMEM; $4.5 \mathrm{~g} / \mathrm{L}$ glucose, $100 \mathrm{U} / \mathrm{ml}$ penicillin, $100 \mu \mathrm{g} / \mathrm{ml}$ streptomycin, $2 \mathrm{~mm}$ glutamine) supplemented with B-27 with antioxidants in normal cell culture condition of $37^{\circ} \mathrm{C}$ in a humid atmosphere of $5 \% \mathrm{CO}_{2}$. Two hours before treatment with various inhibitors and/or $17 \beta$-estradiol, the media was replaced with neurobasal medium supplemented with B-27 without antioxidants.

Cell viability assay. HT-22 and C6-glioma cells were seeded $24 \mathrm{~h}$ before initiation of the experiment at a density of 3500 cells per well in 96-well plates. Cells were exposed to various concentrations of okadaic acid and calyculin A to determine the dose-dependent neurotoxicity of PP inhibitors. In HT-22 cells, $100 \mathrm{~nm}$ okadaic acid, $1 \mathrm{~nm}$ calyculin A, $10 \mathrm{~mm}$ glutamate, and $10 \mu \mathrm{M} 17 \beta$-estradiol were used in the treatment paradigms. In C6-glioma cells, $100 \mathrm{~nm}$ okadaic acid, 500 pm calyculin A, 20 mM glutamate, and $10 \mu \mathrm{M} 17 \beta$-estradiol were used. In primary cortical neurons, $50 \mathrm{~nm}$ okadaic acid, $10 \mathrm{~nm}$ calyculin A, $50 \mu \mathrm{m}$ glutamate, and $100 \mathrm{~nm} 17 \beta$-estradiol were used. After exposure to various treatment paradigms, cells were rinsed with PBS, and cell viability was measured using the membrane-permeant calcein-AM dye (Molecular Probes). Calcein-AM is a fluorogenic esterase substrate that is hydrolyzed to a fluorescent product in cells having esterase activity and intact membranes. Cells were incubated in a solution of $2.5 \mu \mathrm{M}$ calcein-AM in PBS. Twenty minutes later, fluorescence was determined using a Bio-Tek (Winooski, VT) FL600 microplate reader with an excitation/emission filter set of $485 / 530 \mathrm{~nm}$. Cell culture wells treated with methanol served as blanks. The results, obtained in relative fluorescent units, are expressed as the percentage of untreated or vehicle-treated control values.

Immunoblot analysis. Protein from whole-cell lysates $(25 \mu \mathrm{g})$ was separated by SDS-PAGE and transferred to Immunobilon-P polyvinylidene difluoride (Millipore, Bedford, MA) membrane. Membranes were rinsed in Tris-buffered saline (10 mm Tris-base, $\mathrm{pH} 8.0,100 \mathrm{~mm} \mathrm{NaCl}$ ) contain- ing $0.2 \%$ Tween 20 and then blocked with $3 \%$ bovine serum albumin. Blots were then incubated with primary antibodies overnight at $4^{\circ} \mathrm{C}$, rinsed, and incubated in the appropriate secondary antibody before detection using enhanced chemiluminescence (ECL; Pierce Biotechnology, Rockford, IL). ECL results were digitized and quantified using UVP (Upland, CA) Bioimaging System.

Statistical analysis. Statistical significance was determined by one-way ANOVA followed by a Tukey's multiple comparison test. $p<0.05$ was considered significant for all experiments. Each set of data represents three or more individual assays performed separately, with each containing four to eight replicate wells. The values are reported as the mean \pm SEM.

\section{Results \\ Effects of protein phosphatase inhibitors on estrogen- mediated neuroprotection against glutamate-induced cytotoxicity}

To determine the effectiveness of $17 \beta$-estradiol to protect the cells against oxidative stress or excitotoxicity induced by glutamate in the presence of a PP inhibitor, we examined simultaneous treatment of $17 \beta$-estradiol with glutamate and the nonspecific PP inhibitors okadaic acid or calyculin A. Figure 1 shows the results for simultaneous treatment of okadaic acid with $17 \beta$ estradiol in HT-22, C6-glioma, and primary cortical neurons. In the absence of PP inhibitors, $17 \beta$-estradiol was neuroprotective in all three cell types (Fig. 1) against glutamate-induced cytotoxicity. $17 \beta$-Estradiol-mediated neuroprotection against glutamate induced toxicity was abolished in the presence of increasing concentrations of okadaic acid or calyculin A in HT-22, C6-glioma, and primary cortical neurons. Abolition of estrogen protection against glutamate toxicity was seen at $10 \mathrm{~nm}$ okadaic acid in HT-22 and C6 cells and at $5 \mathrm{~nm}$ okadaic acid in primary rat cortical neurons. Results from experiments in which cells were pretreated with $17 \beta$-estradiol for either 2 or $24 \mathrm{~h}$ before addition of glutamate and/or okadaic acid were similar to the simultaneous treatment data (data not shown). The presence of calyculin A (50 pm in HT-22 and primary neurons and 25 pM in C6glioma) also abolished the neuroprotective effects of $17 \beta$ estradiol against oxidative- and excitotoxic stress-induced death caused by glutamate as seen with okadaic acid (data not shown). The concentrations at which either okadaic acid or calyculin A prevented the neuroprotective effects of $17 \beta$-estradiol against glutamate-induced cell death were not neurotoxic in these cells (Fig. 2).

\section{Effect of okadaic acid or calyculin A on cell viability}

To determine the effects of PP inhibition on cell viability, cells were exposed to okadaic acid or calyculin A. Exposure to nonspecific PP inhibitor, okadaic acid, caused a dose-dependent cell death in both HT-22 and C6-glioma cells with an $\mathrm{LD}_{50}$ of 81 and $87 \mathrm{~nm}$, respectively (Fig. $2 \mathrm{~A}$ ). Okadaic acid treatment in primary cortical neurons resulted in a dose-dependent decrease in cell viability similar to results seen in HT-22 and C6-glioma cells; however, okadaic acid was more potent in primary neurons, with an $\mathrm{LD}_{50}$ of $40 \mathrm{~nm}$ (Fig. 2A).

Calyculin A, a PP1 and PP2A inhibitor, also showed a dosedependent decrease in viability in all three cell types (Fig. 2 B). Cell viability decreased precipitously at a threshold concentration of 500 pM in C6-glioma cells, whereas HT-22 cells exhibited a more typical dose-dependent response with a $50 \%$ decrease in cell viability with $>500 \mathrm{pm}$ treatment. Calyculin A decreased cell viability in a dose-dependent manner in primary cortical neurons with a $\mathrm{LD}_{50}$ of $67 \mathrm{pm}$ (Fig. $2 \mathrm{~B}$ ). 


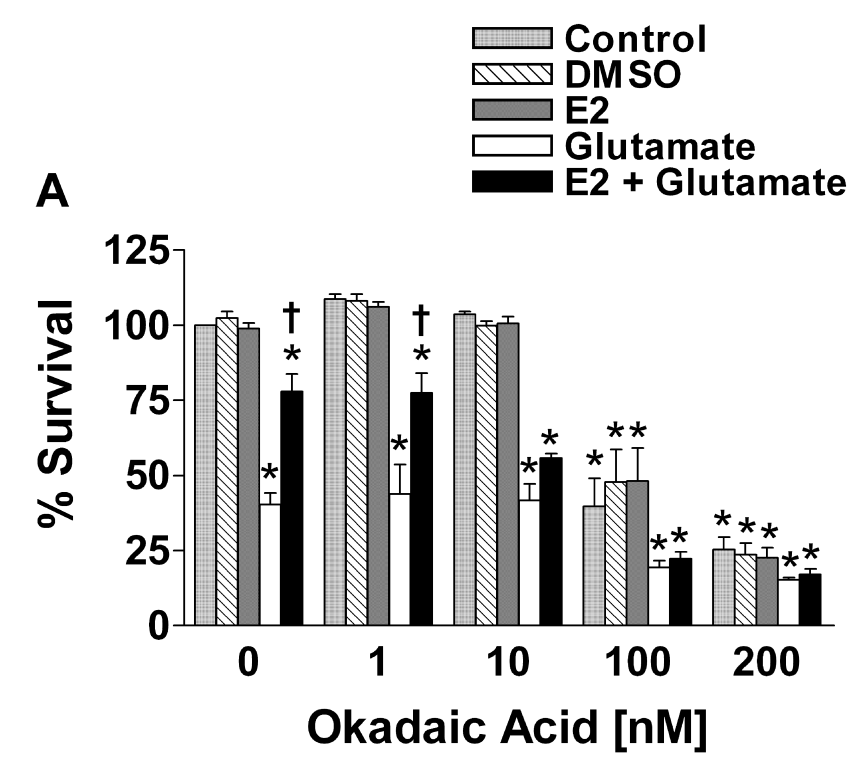

B

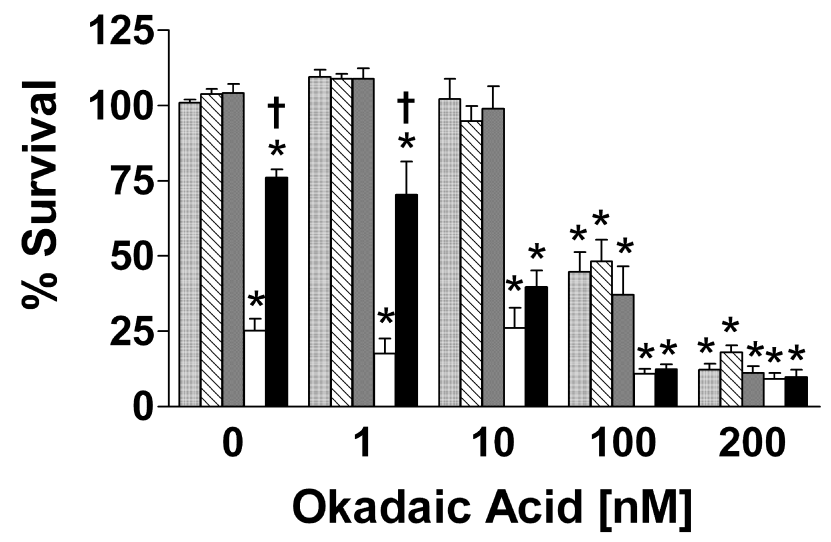

C

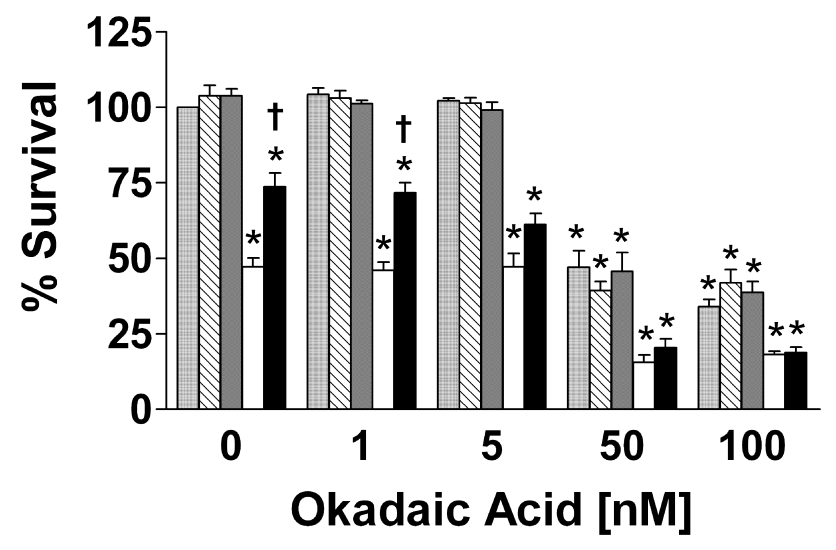

Figure 1. Effects of okadaic acid on estrogen-mediated neuroprotection from glutamate neurotoxicity. HT-22 cells (passages 18-25), (6-glioma cells (passages 40-49), or primary rat cortical neurons were seeded into 96 -well plates at a density of 3500 or 25,000 cells per well. $A, H$ HT-22 cells treated simultaneously with $100 \mathrm{~nm}$ okadaic acid, $10 \mathrm{~mm}$ glutamate, and/or $10 \mu \mathrm{m} 17 \beta$-estradiol. $\boldsymbol{B}$, C6-glioma cells treated simultaneously with $100 \mathrm{~nm}$ okadaic acid, $20 \mathrm{~mm}$ glutamate, and/or $10 \mu \mathrm{m}$ $17 \beta$-estradiol. C, Primary cortical neurons treated simultaneously with $50 \mathrm{~nm}$ okadaic acid, $50 \mu \mathrm{m}$ glutamate, and/or $100 \mathrm{~nm} 17 \beta$-estradiol. Cell viability was determined by calcein AM assay after $24 \mathrm{~h}$ exposure to the various compounds. All data were normalized to percentage survival of vehicle control. Data are represented as mean \pm SEM for $n=6 .{ }^{*} p<0.05$ versus vehicle control; ${ }^{\dagger} p<0.05$ versus glutamate-treated group.

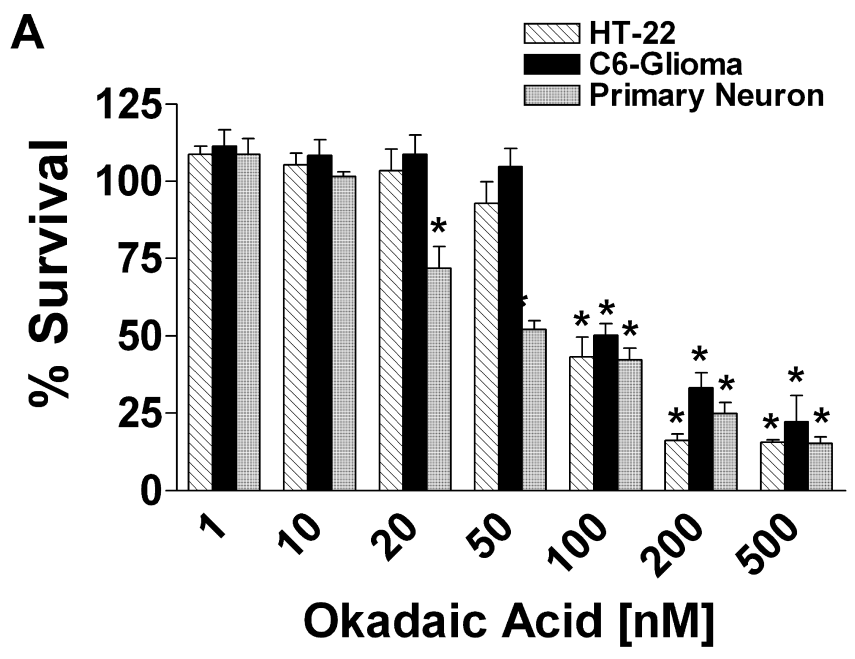

B

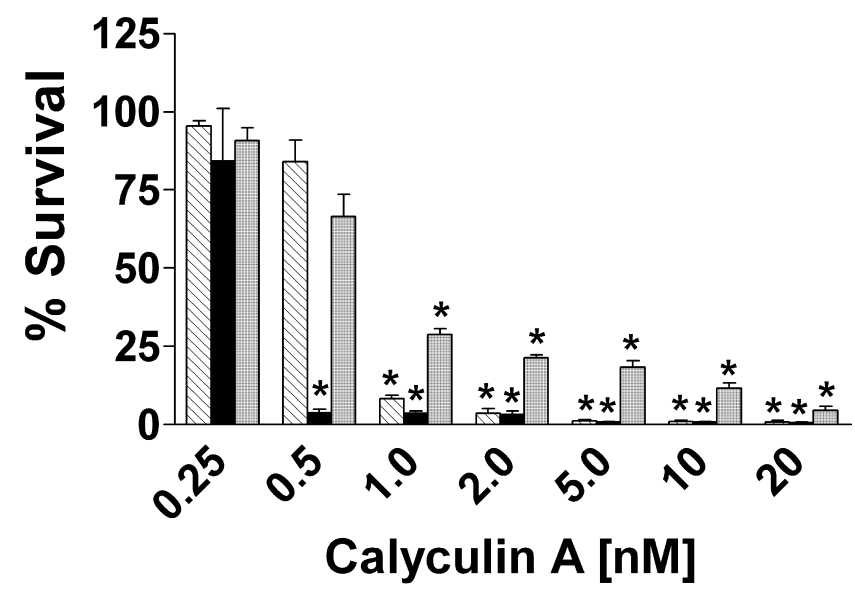

Figure 2. Dose-dependent neurotoxicity of okadaic acid $(\boldsymbol{A})$ and calyculin $A(\boldsymbol{B})$. HT-22 cells (passages 18 -25) and (6-glioma cells (passages $40-49$ ) were seeded into 96-well plates at a density of 3500 cells per well, and primary rat cortical neurons were seeded into 96 -well plates at a density of 25,000 cells per well. 0 kadaic acid or calyculin A were added at varying concentrations. Cell viability was determined by calcein AM assay after $24 \mathrm{~h}$ exposure to the various protein phosphatase inhibitors. All data were normalized to percentage survival of vehicle control. Data are represented as mean $\pm \operatorname{SEM}$ for $n=6 .{ }^{*} p<0.05$ versus vehicle control.

Estrogens did not prevent the protein phosphatase inhibitorinduced cell death

$17 \beta$-Estradiol is a potent neuroprotectant; therefore, to assess the neuroprotective effects of $17 \beta$-estradiol, cells were exposed to $17 \beta$-estradiol simultaneously, 2 or 24 h before treatment with neurotoxic concentrations of okadaic acid or calyculin A. Neither simultaneous nor 2 or $24 \mathrm{~h}$ pretreatment with $17 \beta$-estradiol protected HT-22, C6-glioma, or primary rat cortical neurons against okadaic acid- or calyculin A-induced cell death (Fig. 3). The $24 \mathrm{~h}$ pretreatment results are not shown but were same as those presented in Figure 3.

Time-dependent effects of $17 \beta$-estradiol and/or glutamate PP2A protein levels

We examined the time course of the response of PP2A protein expression to treatment with glutamate and/or $17 \beta$-estradiol in HT-22 cells. Glutamate treatment $(10 \mathrm{mM})$ caused a reduction in PP2A levels that was significant at $30 \mathrm{~min}$, and a $50 \%$ or greater reduction persisted through $24 \mathrm{~h}$ of treatment (Fig. 4). 17 $\beta$ - 
Estradiol $(10 \mu \mathrm{M})$ alone did not significantly affect PP2A levels at any given time compared with untreated controls. However, simultaneous treatment with $17 \beta$ estradiol and glutamate caused a rapid and profound increase in PP2A expression at 15 and $30 \mathrm{~min}$, followed by a return to normal levels by $1 \mathrm{~h}$ after treatment that persisted through $24 \mathrm{~h}$ treatment.

Effects of $17 \beta$-estradiol on PP1, PP2A, and $\mathrm{PP} 2 \mathrm{~B}$ protein expression

Treatment of HT-22 cells with $10 \mu \mathrm{M} 17 \beta$ estradiol alone for $24 \mathrm{~h}$ did not show any effect on the expressions of any PP compared with untreated control cells (Fig. 5). However, $24 \mathrm{~h}$ of $10 \mathrm{~mm}$ glutamate treatment caused a marked decrease in protein levels of PP1, PP2A, and PP2B in HT-22 cells (Fig. 5). Simultaneous treatment with $17 \beta$-estradiol in the presence of $10 \mathrm{~mm}$ glutamate restored $\mathrm{PP} 1$ and $\mathrm{PP} 2 \mathrm{~A}$ protein expression to levels comparable with untreated control cells (Fig. 5); however, although there was a tendency for increased PP2B expression with simultaneous estrogen treatment, the difference was not statistically significant. The attenuation of glutamate induced declines in phosphatase expression by estrogen was abolished in the presence of $100 \mathrm{~nm}$ okadaic acid.

Primary rat cortical neurons showed a pattern similar to that seen in HT-22 cells (Fig. 6). As in HT-22 cells, PP1, PP2A, and $\mathrm{PP} 2 \mathrm{~B}$ protein expressions were decreased after $50 \mu \mathrm{M}$ glutamate. The decrease in protein expression caused by glutamate was attenuated with simultaneous $100 \mathrm{nM}$ $17 \beta$-estradiol treatment. Additionally, $17 \beta$-estradiol was unable to prevent the glutamate mediated decrease in protein expressions of PP1, PP2A, and PP2B in the presence of $50 \mathrm{~nm}$ okadaic acid.

\section{Discussion}

The present study reports several significant findings. First, we confirmed that PP inhibitors are potent neurotoxins in transformed neuronal and glial cell types as well as in primary cortical neurons. Second, we demonstrated for the first time that estrogen treatment regimens that are protective against other neurotoxic insults do not protect against the toxic effects of the PP inhibitors. Third, the protective effects of estrogens against glutamate toxicity are antagonized by phosphatase inhibition.

Finally, estrogens antagonize the reduction in PP1, PP2A, and $\mathrm{PP} 2 \mathrm{~B}$ induced by glutamate but not in the presence of okadaic acid. Collectively, these data support the hypothesis that phosphatase induction is a major component of estrogen-mediated neuroprotection.

PP inhibitors are well known cytotoxins. Okadaic acid is a

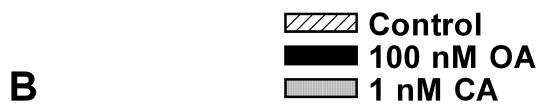

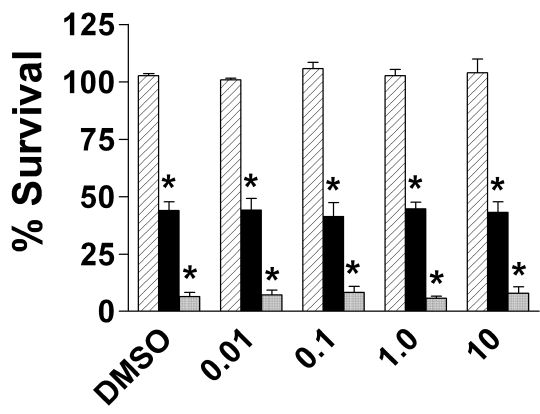

$17 \beta$-Estradiol $[\mu \mathrm{M}]$

C

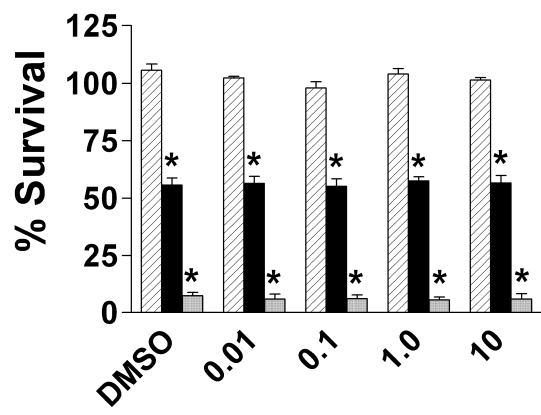

$17 \beta$-Estradiol $[\mu \mathrm{M}]$

E

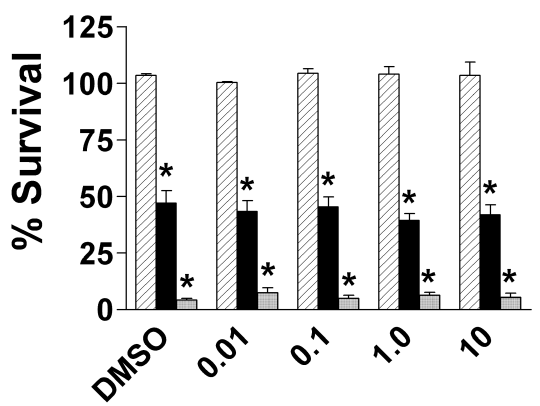

$17 \beta$-Estradiol $[\mu \mathrm{M}]$

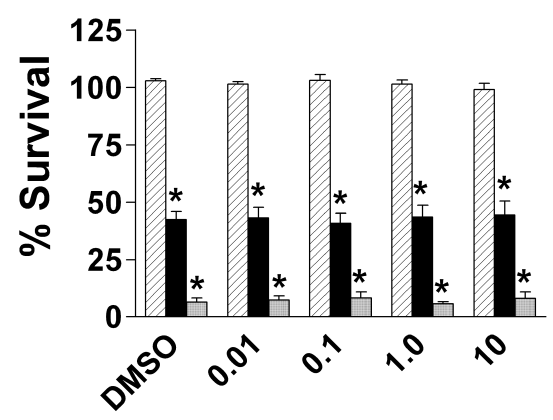

$2 \mathrm{hr}$ Pre $17 \beta-\mathrm{E} 2[\mu \mathrm{M}]$

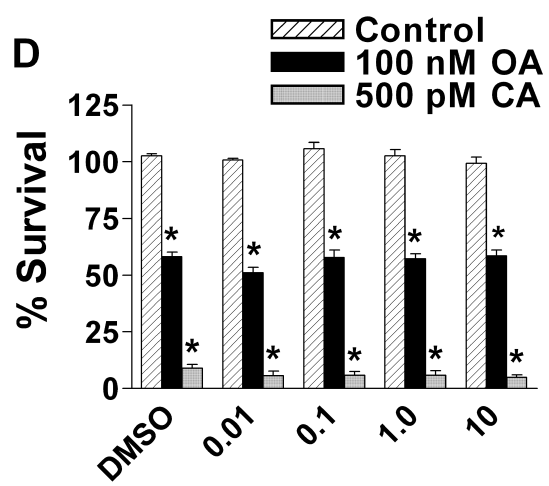

$2 \mathrm{hr}$ Pre 17 $\beta$-E2 $[\mu \mathrm{M}]$

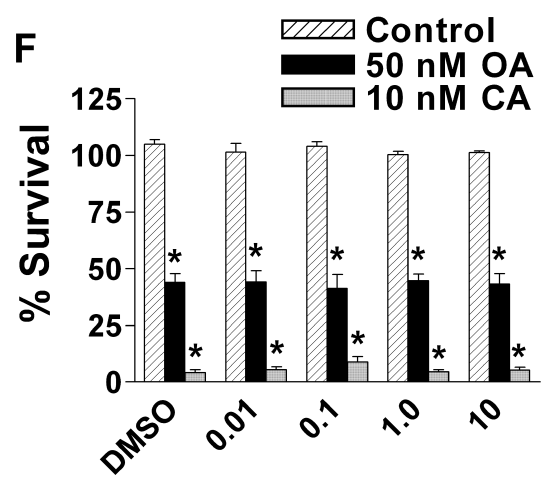

$2 \mathrm{hr}$ Pre $17 \beta$-E2 $[\mu \mathrm{M}]$
Figure 3. Effects of $17 \beta$-estradiol on okadaic acid- or calyculin A-induced neurotoxicity. HT-22 cells (passages 18-25) and C6-glioma cells (passages 40 -49) were seeded into 96-well plates at a density of 3500 cells per well, and primary rat cortical neurons were seeded into 96 -well plates at a density of 25,000 cells per well. HT-22 cells treated with $100 \mathrm{~nm}$ okadaic acid or $1 \mathrm{~nm}$ calyculin $A$ and simultaneous (A) or $2 \mathrm{~h}$ pretreatment $(\boldsymbol{B})$ of $17 \beta$-estradiol (E2) at varying concentrations are shown. (6-glioma cells treated with $100 \mathrm{~nm}$ okadaic acid or 500 pm calyculin $A$ and simultaneous $(\boldsymbol{C})$ or $2 \mathrm{~h}$ pretreatment $(\boldsymbol{D})$ of $17 \beta$-estradiol at varying concentrations are shown. Primary cortical neurons treated with $50 \mathrm{~nm}$ okadaic acid or $10 \mathrm{~nm}$ calyculin $A$ and simultaneous $(\boldsymbol{E})$ or $2 \mathrm{~h}$ pretreatment $(\boldsymbol{F})$ of $17 \beta$-estradiol at varying concentrations are shown. Cell viability was determined by calcein AM assay after $24 \mathrm{~h}$ exposure to the various protein phosphatase inhibitors and $17 \beta$-estradiol. All data were normalized to percentage survival of vehicle control. Data are represented as mean \pm SEM for $n=6 .{ }^{*} p<0.05$ versus vehicle control.

potent inhibitor of PP1 and PP2A at low concentrations (10 and $0.1 \mathrm{nM}$, respectively). It is also an inhibitor of $\mathrm{PP} 2 \mathrm{~B}$ at higher micromolar concentrations. In the present study, we observed a dose-dependent neurotoxic effect of okadaic acid in HT-22, C6glioma, and primary cortical neurons. The neurotoxic effects of okadaic acid were clear with doses as low as $50 \mathrm{~nm}$ in primary 
A. Glutamate

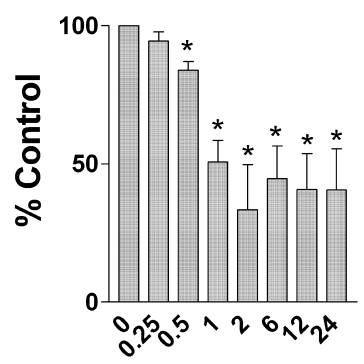

Hours
B. $17 \beta$-Estradiol

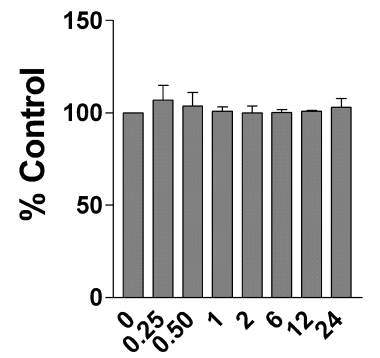

Hours

\section{C. $17 \beta-E 2+$ Glutamate}

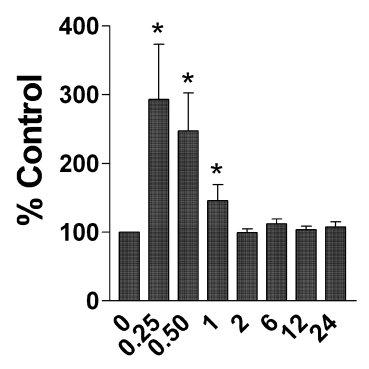

Hours

Figure 4. Time course of the effects $17 \beta$-estradiol $(\boldsymbol{B})$, glutamate $(\boldsymbol{A})$, and their combination $(\boldsymbol{C})$ on PP2A protein levels. HT-22 cells were treated with $10 \mathrm{~mm}$ glutamate and/or $10 \mu \mathrm{m} 17 \beta$-estradiol. Cells were harvested at the times indicated for Western blot analysis of PP2A. The graphs represent relative $0 \mathrm{D}$ as a percentage of time 0 control. Data are represented as mean \pm SEM for $n=$ 3. ${ }^{*} p<0.05$ versus time 0 control.

\section{A. PP1}
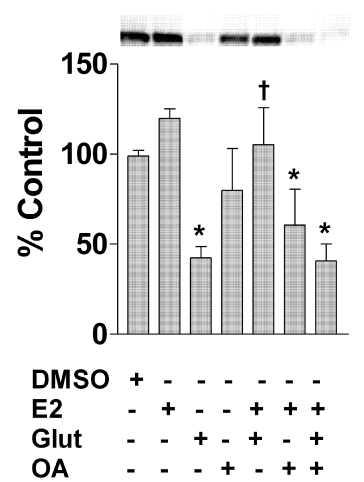

B. PP2A

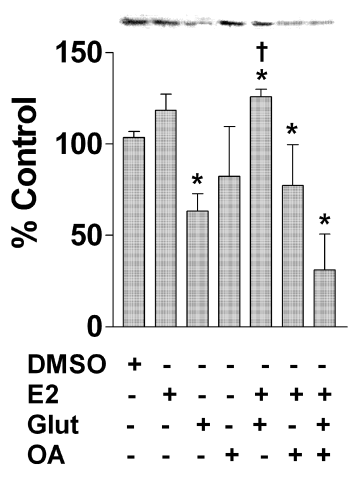

C. PP2B

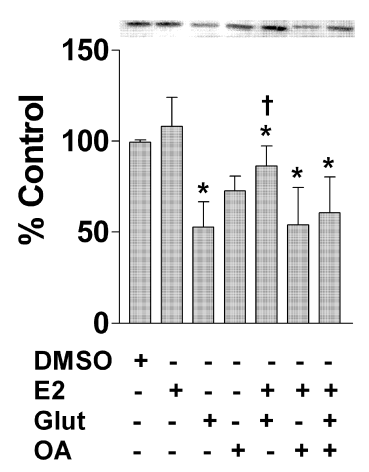

Figure 5. PP1 $(\boldsymbol{A}), \mathrm{PP} 2 \mathrm{~A}(\boldsymbol{B})$, and PP2B ( $C$ protein levels in response to $17 \beta$-estradiol in the presence and absence glutamate and/or okadaic acid in HT-22 cells. HT-22 cells were treated with $100 \mathrm{~nm}$ okadaic acid (OA), $10 \mathrm{~mm}$ glutamate (Glut), and/or $10 \mu \mathrm{m}$ $17 \beta$-estradiol (E2). Cells were harvested after $24 \mathrm{~h}$ of treatment for Western blot analysis of PP1, PP2A, and PP2B. Data are represented as mean \pm SEM for $n=3 .{ }^{*} p<0.05$ versus control; ${ }^{\dagger} p<0.05$ versus glutamate-treated group.

A. PP1

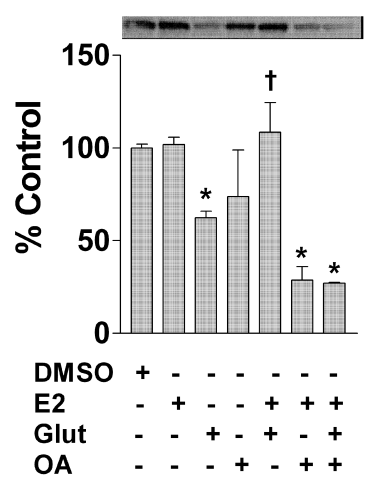

B. PP2A

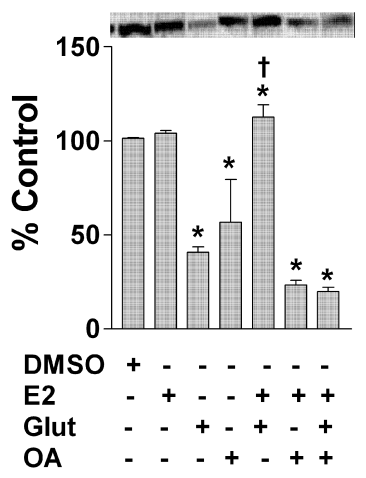

\section{PP2B}

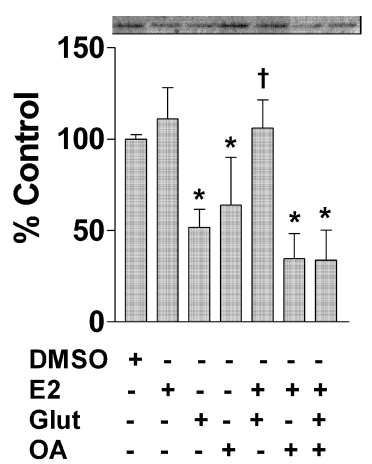

Figure 6. PP1 (A), PP2A (B), and PP2B ( () protein levels in response to $17 \beta$-estradiol in the presence and absence of $50 \mu \mathrm{m}$ glutamate and/or $50 \mathrm{~nm}$ okadaic acid in primary cortical neurons. Primary rat cortical neurons were treated with $50 \mathrm{~nm}$ okadaic acid (OA), $50 \mu \mathrm{m}$ glutamate (Glut), and/or $100 \mathrm{~nm} 17 \beta$-estradiol (E2). Cells were harvested after $24 \mathrm{~h}$ of treatment for Western blot analysis of PP1, PP2A, and PP2B. Data are represented as mean \pm SEM for $n=3 .{ }^{*} p<0.05$ versus control; ${ }^{\dagger} p<0.05$ versus glutamate-treated group.

neurons, which is in agreement with studies by other laboratories (Fernandez et al., 1991; Candeo et al., 1992; Nuydens et al., 1998; Kim et al., 2000). Numerous studies have also shown okadaic acid to be cytotoxic in a variety of other cell types (Morimoto et al.,
1999, 2004; Huynh-Delerme et al., 2003; Parameswaran et al., 2004). Calyculin A is also a potent inhibitor of PP1 and PP2A. Calyculin A induces apoptosis in osteoblastic cells (Morimoto et al., 1997), oral squamous carcinoma cells (Fujita et al., 1999), submandibular gland cells (Morimoto et al., 1999), and neuronal cells (Ko et al., 2000; Li et al., 2004). In our hands, calyculin A was a more potent neurotoxin than okadaic acid. The inability of $17 \beta$-estradiol to protect cells against the neurotoxic effects of okadaic acid and calyculin A supports the argument that PP are involved in the neuroprotective effects of $17 \beta$-estradiol against glutamate-induced oxidative stress and excitotoxicity.

Numerous studies from this laboratory, as well as others, have established clearly that estrogen compounds are potent neuroprotective agents, both in vitro and in vivo (for review, see Behl and Manthey, 2000; Green and Simpkins, 2000; Garcia-Segura et al., 2001; Lee and McEwen, 2001; Wise et al., 2001). These effects are mediated at least in part through the rapid but acute phosphorylation of signaling proteins such as adenylyl cyclase, Akt, protein kinase A, PKC, and MAPK (mitogen-activated protein kinase) (Migliaccio et al., 1996; Kelly and Wagner, 1999; Singh et al., 1999; Zhang et al., 2001). Changes in the activity of these enzymes can regulate the phosphorylation of numerous cellular substrates including intermediary signaling proteins such as Rsk, p38, and c-Jun N-terminal protein kinase as well as the nuclear transcriptional factors cAMP response element-binding protein and cfos/cjun, which may ultimately mediate cell survival changes (for review, see Lee and McEwen, 2001).

The present study provides a potential mechanism for these effects of estrogens, through the prevention of insult-induced decrease in phosphatase activity and the resulting neurotoxic, persistent hyperphosphorylation of proteins in multiple signaling pathways. We have demonstrated that the neuroprotective effects of estrogens against glutamate toxicity are blocked by phosphatase inhibition and that estrogens prevent insult-induced reduction in protein phosphatase levels, suggesting that protein phosphatases play a role in estrogen-mediated neuroprotection against neurotoxic effects of oxidative stress and excitotoxicity.

A specific consideration of the effects of estrogens on signaling in the ERK1/2 pathway is informative. Estrogens cause a rapid, transient phosphorylation of ERK1/2 in neuroblastoma (Watters et al., 1997), non-neuronal cells (Migliaccio et al., 1996), and 
cortical explants (Singh et al., 1999), as well as in the cortex of estrogen receptor- $\alpha$ knock-out mice (Singh et al., 2000). This transient phosphorylation of ERK1/2 is believed to mediate a neuroprotective signal, whereas persistent phosphorylation of ERK1/2 is associated with apoptosis, likely through nuclear translocation and retention of phosphorylated ERK1/2 (Kuperstein and Yavin, 2002; Kins et al., 2003). The transient nature of neuroprotective signaling indicates that dephosphorylation through activation of phosphatases is required. Indeed, pharmacological inhibition of ERK1/2 signaling is neuroprotective in a number of cell model systems (Murray et al., 1998; Barone et al., 2001), including the HT-22 cell oxidative stress model used in our studies (Satoh et al., 2000; Stanciu et al., 2000). Similarly, in models of stroke, brain trauma, and neurodegenerative diseases, there are detrimental effects of persistent activation of ERK1/2 during oxidative neuronal injury as well as excitotoxic injury (Alessandrini et al., 1999; Slevin et al., 2000; Stanciu et al., 2000; Zhu et al., 2002a,b; Ferrer et al., 2003; Harper and Wilkie, 2003; Wang et al., 2003, 2004).

A variety of insults have been shown to cause the hyperphosphorylation of tau (Guttmann et al., 1995; Schweers et al., 1995). The present data may provide a mechanism by which estrogens ameliorate the effect of insult on tau hyperphosphorylation in vitro (Alvarez-de-la-Rosa et al., 2005) and in ischemia/ reperfusion-induced injury in vivo (Wen et al., 2004). By preventing insult-induced decreases in protein phosphatases, estrogens could allow for the dephosphorylation of tau even in the face of an insult stimulation of tau phosphorylation. This could contribute to the beneficial effects of early postmenopausal estrogen therapy on the development of AD (Paganini-Hill and Henderson, 1994; Tang et al., 1996; Zandi et al., 2002; Bagger et al., 2005).

The mechanism by which estrogens increase protein phosphatase levels is not known. To date, we are not aware of an estrogen response element in the regulatory regions of the protein phosphatases under study. Therefore, we hypothesize that protein phosphatase signaling is through an alternative pathway. One intriguing possibility is that the signaling pathways activated by neurotoxic insults suppress phosphatase expression or enhance the proteolytic breakdown of these important proteins. Estrogens then could induce an increase in phosphatase production and/or reduce proteolysis thereby normalizing protein phosphatase levels and regulating signaling along phosphorylation-dependent pathways.

We find it remarkable that all three protein phosphatases appear to respond similarly to estradiol, glutamate, okadaic acid, and their combination in HT-22, C6-glioma, and primary neuronal cultures. The robust decrease in these three protein phosphatases in response to glutamate in a model of oxidative stress (HT-22 and C6-glioma cells) and to excitotoxicity (primary cortical neurons) suggests that protein phosphatase inhibition may be a common neurotoxic event for these insults. Similarly, the ability of estrogens to antagonize these glutamate-induced reductions in protein phosphatases suggests that this action is common to estrogen protection in both oxidative stress and excitotoxicity in neurons. In addition, experimental data from various studies have shown not only the ability of estrogen to protect glial cells from various toxins (Bishop and Simpkins, 1994; Haghighat et al., 2004; Takao et al., 2004) but also the mediation of glial cells in estrogen neuroprotection (Sortino et al., 2004; Wynne and Saldanha, 2004). Therefore, it is important to understand the mechanism of estrogen actions in both neurons and glia. The results from the present study suggest that there is a common mechanism of neuroprotection by estrogens in neuronal and glial cells.
Although accumulating evidence from experimental studies using cell and animal models suggests that estrogens are potent neuroprotective agents against multiple types of neurodegenerative diseases and injuries, recent clinical studies have reported either inconclusive or untoward effects of hormone therapy on the brain (Mulnard et al., 2000; Rapp et al., 2003; Shumaker et al., 2003, 2004; Espeland et al., 2004). The discrepancies in the results of basic science and clinical studies has been addressed by several recent reports (Brinton, 2003; Simpkins and Singh, 2004; Singh and Simpkins, 2005) and may be explained by a number of factors, including the preparation of the estrogen and progesterone used in the Women's Health Initiative Memory (WHIM) studies, the continuous exposure regimen, the advanced age of the women at the initiation of hormone or estrogen therapy, and the cardiovascular health of the women (Singh and Simpkins, 2005). It remains unknown to what extent these conditions of the WHIM studies contribute to the aforementioned differences in the reported effects of hormone therapy.

In summary, we have demonstrated that estrogen-mediated neuroprotection is antagonized by protein phosphatase inhibition in a manner associated with estrogen-induced increases in protein phosphatase levels. These data provide support for the hypothesis that estrogen-induced neuroprotection is mediated by protein phosphatases.

\section{References}

Alessandrini A, Namura S, Moskowitz MA, Bonventre JV (1999) MEK1 protein kinase inhibition protects against damage resulting from focal cerebral ischemia. Proc Natl Acad Sci USA 96:12866-12869.

Alkayed NJ, Harukuni I, Kimes AS, London ED, Traystman RJ, Hurn PD (1998) Gender-linked brain injury in experimental stroke. Stroke 29: 159-165, 166 [discussion].

Alvarez-de-la-Rosa M, Silva I, Nilsen J, Pérez MM, Miguel García-Segura L, Ávila J, Naftolin F (2005) Estradiol prevents neural tau hyperphosphorylation characteristic of Alzheimer's disease. In: The future of hormone therapy: what basic science and clinical studies teach us, Vol 1052 (Singh M, Simpkins JW, eds), pp 210-224. New York: New York Academy of Science.

Bagger YZ, Tanko LB, Alexandersen P, Qin G, Christiansen C (2005) Early postmenopausal hormone therapy may prevent cognitive impairment later in life. Menopause 12:12-17.

Barone FC, Irving EA, Ray AM, Lee JC, Kassis S, Kumar S, Badger AM, Legos JJ, Erhardt JA, Ohlstein EH, Hunter AJ, Harrison DC, Philpott K, Smith BR, Adams JL, Parsons AA (2001) Inhibition of p38 mitogen-activated protein kinase provides neuroprotection in cerebral focal ischemia. Med Res Rev 21:129-145.

Behl C, Manthey D (2000) Neuroprotective activities of estrogen: an update. J Neurocytol 29:351-358.

Bi R, Broutman G, Foy MR, Thompson RF, Baudry M (2000) The tyrosine kinase and mitogen-activated protein kinase pathways mediate multiple effects of estrogen in hippocampus. Proc Natl Acad Sci USA 97:3602-3607.

Bishop J, Simpkins JW (1994) Estradiol treatment increases viability of glioma and neuroblastoma cells in vitro. Mol Cell Neurosci 5:303-308.

Brinton RD, Nilsen J (2003) Effects of estrogen plus progestin on risk of dementia. JAMA 290:1706.

Candeo P, Favaron M, Lengyel I, Manev RM, Rimland JM, Manev H (1992) Pathological phosphorylation causes neuronal death: effect of okadaic acid in primary culture of cerebellar granule cells. J Neurochem 59:1558-1561.

Dubal DB, Kashon ML, Pettigrew LC, Ren JM, Finklestein SP, Rau SW, Wise PM (1998) Estradiol protects against ischemic injury. J Cereb Blood Flow Metab 18:1253-1258.

Espeland MA, Rapp SR, Shumaker SA, Brunner R, Manson JE, Sherwin BB, Hsia J, Margolis KL, Hogan PE, Wallace R, Dailey M, Freeman R, Hays J (2004) Conjugated equine estrogens and global cognitive function in postmenopausal women: Women's Health Initiative Memory Study. JAMA 291:2959-2968.

Fernandez MT, Zitko V, Gascon S, Novelli A (1991) The marine toxin oka- 
daic acid is a potent neurotoxin for cultured cerebellar neurons. Life Sci 49:PL157-PL162.

Fernandez-Sanchez MT, Garcia-Rodriguez A, Diaz-Trelles R, Novelli A (1996) Inhibition of protein phosphatases induces IGF-1-blocked neurotrophin-insensitive neuronal apoptosis. FEBS Lett 398:106-112.

Ferrer I, Friguls B, Dalfo E, Planas AM (2003) Early modifications in the expression of mitogen-activated protein kinase (MAPK/ERK), stressactivated kinases SAPK/JNK and p38, and their phosphorylated substrates following focal cerebral ischemia. Acta Neuropathol (Berl) 105:425-437.

Fujita M, Seta C, Fukuda J, Kobayashi S, Haneji T (1999) Induction of apoptosis in human oral squamous carcinoma cell lines by protein phosphatase inhibitors. Oral Oncol 35:401-408.

Fukuda K, Yao H, Ibayashi S, Nakahara T, Uchimura H, Fujishima M, Hall ED (2000) Ovariectomy exacerbates and estrogen replacement attenuates photothrombotic focal ischemic brain injury in rats. Stroke $31: 155-160$.

Garcia-Segura LM, Azcoitia I, DonCarlos LL (2001) Neuroprotection by estradiol. Prog Neurobiol 63:29-60.

Garver TD, Lehman RA, Billingsley ML (1996) Microtubule assembly competence analysis of freshly-biopsied human tau, dephosphorylated tau, and Alzheimer tau. J Neurosci Res 44:12-20.

Gong CX, Singh TJ, Grundke-Iqbal I, Iqbal K (1993) Phosphoprotein phosphatase activities in Alzheimer disease brain. J Neurochem 61:921-927.

Green PS, Simpkins JW (2000) Neuroprotective effects of estrogens: potential mechanisms of action. Int J Dev Neurosci 18:347-358.

Green PS, Gridley KE, Simpkins JW (1996) Estradiol protects against betaamyloid (25-35)-induced toxicity in SK-N-SH human neuroblastoma cells. Neurosci Lett 218:165-168.

Green PS, Bishop J, Simpkins JW (1997a) $17 \alpha$-estradiol exerts neuroprotective effects on SK-N-SH cells. J Neurosci 17:511-515.

Green PS, Gordon K, Simpkins JW (1997b) Phenolic A ring requirement for the neuroprotective effects of steroids. J Steroid Biochem Mol Biol 63:229-235.

Green PS, Gridley KE, Simpkins JW (1998) Nuclear estrogen receptorindependent neuroprotection by estratrienes: a novel interaction with glutathione. Neuroscience 84:7-10.

Gridley KE, Green PS, Simpkins JW (1997) Low concentrations of estradiol reduce beta-amyloid (25-35)-induced toxicity, lipid peroxidation and glucose utilization in human SK-N-SH neuroblastoma cells. Brain Res 778:158-165.

Guttmann RP, Erickson AC, Johnson GV (1995) Tau self-association: stabilization with a chemical cross-linker and modulation by phosphorylation and oxidation state. J Neurochem 64:1209-1215.

Haghighat N, Oblinger MM, McCandless DW (2004) Cytoprotective effect of estrogen on ammonium chloride-treated C6-glioma cells. Neurochem Res 29:1359-11364.

Harper SJ, Wilkie N (2003) MAPKs: new targets for neurodegeneration. Expert Opin Ther Targets 7:187-200.

Harris KA, Oyler GA, Doolittle GM, Vincent I, Lehman RA, Kincaid RL, Billingsley ML (1993) Okadaic acid induces hyperphosphorylated forms of tau protein in human brain slices. Ann Neurol 33:77-87.

Huynh-Delerme C, Fessard V, Kiefer-Biasizzo H, Puiseux-Dao S (2003) Characteristics of okadaic acid-induced cytotoxic effects in CHO K1 cells. Environ Toxicol 18:383-394.

Jung ME, Gatch MB, Simpkins JW (2005) Estrogen neuroprotection against the neurotoxic effects of ethanol withdrawal: potential mechanisms. Exp Biol Med (Maywood) 230:8-22.

Kelly MJ, Wagner EJ (1999) Estrogen modulation of G-protein-coupled receptors. Trends Endocrinol Metab 10:369-374.

Kim DH, Hong HN, Lee JH, Park HS (2000) Okadaic acid induces cycloheximide and caspase sensitive apoptosis in immature neurons. Mol Cells 10:83-89.

Kins S, Kurosinski P, Nitsch RM, Gotz J (2003) Activation of the ERK and JNK signaling pathways caused by neuron-specific inhibition of PP2A in transgenic mice. Am J Pathol 163:833-843.

Ko HW, Han KS, Kim EY, Ryu BR, Yoon WJ, Jung YK, Kim SU, Gwag BJ (2000) Synergetic activation of p38 mitogen-activated protein kinase and caspase-3-like proteases for execution of calyculin A-induced apoptosis but not $\mathrm{N}$-methyl-D-aspartate-induced necrosis in mouse cortical neurons. J Neurochem 74:2455-2461.

Kuperstein F, Yavin E (2002) ERK activation and nuclear translocation in amyloid-beta peptide- and iron-stressed neuronal cell cultures. Eur J Neurosci 16:44-54.

Kuroki Y, Fukushima K, Kanda Y, Mizuno K, Watanabe Y (2000) Putative membrane-bound estrogen receptors possibly stimulate mitogenactivated protein kinase in the rat hippocampus. Eur J Pharmacol 400:205-209.

Lee SJ, McEwen BS (2001) Neurotrophic and neuroprotective actions of estrogens and their therapeutic implications. Annu Rev Pharmacol Toxicol 41:569-591.

Li SP, Deng YQ, Wang XC, Wang YP, Wang JZ (2004) Melatonin protects SH-SY5Y neuroblastoma cells from calyculin A-induced neurofilament impairment and neurotoxicity. J Pineal Res 36:186-191.

Lian Q, Ladner CJ, Magnuson D, Lee JM (2001) Selective changes of calcineurin (protein phosphatase 2B) activity in Alzheimer's disease cerebral cortex. Exp Neurol 167:158-165.

Malchiodi-Albedi F, Petrucci TC, Picconi B, Iosi F, Falchi M (1997) Protein phosphatase inhibitors induce modification of synapse structure and tau hyperphosphorylation in cultured rat hippocampal neurons. J Neurosci Res 48:425-438.

Mendelowitsch A, Ritz MF, Ros J, Langemann H, Gratzl O (2001) 17betaEstradiol reduces cortical lesion size in the glutamate excitotoxicity model by enhancing extracellular lactate: a new neuroprotective pathway. Brain Res 901:230-236.

Merrick SE, Trojanowski JQ, Lee VM (1997) Selective destruction of stable microtubules and axons by inhibitors of protein serine/threonine phosphatases in cultured human neurons. J Neurosci 17:5726-5737.

Migliaccio A, Di Domenico M, Castoria G, de Falco A, Bontempo P, Nola E, Auricchio F (1996) Tyrosine kinase/p21ras/MAP-kinase pathway activation by estradiol-receptor complex in MCF-7 cells. EMBO J 15:1292-1300.

Morimoto H, Okamura H, Yoshida K, Kitamura S, Haneji T (2004) Okadaic acid induces apoptosis through double-stranded RNA-dependent protein kinase/eukaryotic initiation factor-2alpha pathway in human osteoblastic MG63 cells. J Biochem (Tokyo) 136:433-438.

Morimoto Y, Ohba T, Kobayashi S, Haneji T (1997) The protein phosphatase inhibitors okadaic acid and calyculin A induce apoptosis in human osteoblastic cells. Exp Cell Res 230:181-186.

Morimoto Y, Morimoto H, Kobayashi S, Ohba T, Haneji T (1999) The protein phosphatase inhibitors, okadaic acid and calyculin A, induce apoptosis in human submandibular gland ductal cell line HSG cells. Oral Dis 5:104-110.

Mulnard RA, Cotman CW, Kawas C, van Dyck CH, Sano M, Doody R, Koss E, Pfeiffer E, Jin S, Gamst A, Grundman M, Thomas R, Thal LJ (2000) Estrogen replacement therapy for treatment of mild to moderate Alzheimer disease: a randomized controlled trial. Alzheimer's Disease Cooperative Study. JAMA 283:1007-1015.1

Murray B, Alessandrini A, Cole AJ, Yee AG, Furshpan EJ (1998) Inhibition of the p44/42 MAP kinase pathway protects hippocampal neurons in a cell-culture model of seizure activity. Proc Natl Acad Sci USA 95:11975-11980.

Nuydens R, de Jong M, Van Den Kieboom G, Heers C, Dispersyn G, Cornelissen F, Nuyens R, Borgers M, Geerts H (1998) Okadaic acid-induced apoptosis in neuronal cells: evidence for an abortive mitotic attempt. J Neurochem 70:1124-1133.

Paganini-Hill A, Henderson VW (1994) Estrogen deficiency and risk of Alzheimer's disease in women. Am J Epidemiol 140:256-261.

Parameswaran N, Spielman WS, Brooks DP, Nambi P (2004) Okadaic acid stimulates caspase-like activities and induces apoptosis of cultured rat mesangial cells. Mol Cell Biochem 260:7-11.

Perry G, Cash AD, Smith MA (2002) Alzheimer disease and oxidative stress. J Biomed Biotechnol 2:120-123.

Rapp SR, Espeland MA, Shumaker SA, Henderson VW, Brunner RL, Manson JE, Gass ML, Stefanick ML, Lane DS, Hays J, Johnson KC, Coker LH, Dailey M, Bowen D (2003) Effect of estrogen plus progestin on global cognitive function in postmenopausal women: the Women's Health Initiative Memory Study: a randomized controlled trial. JAMA 289:2663-2672.

Saito T, Ishiguro K, Uchida T, Miyamoto E, Kishimoto T, Hisanaga S (1995) In situ dephosphorylation of tau by protein phosphatase $2 \mathrm{~A}$ and $2 \mathrm{~B}$ in fetal rat primary cultured neurons. FEBS Lett 376:238-242.

Satoh T, Nakatsuka D, Watanabe Y, Nagata I, Kikuchi H, Namura S (2000) Neuroprotection by MAPK/ERK kinase inhibition with U0126 against 
oxidative stress in a mouse neuronal cell line and rat primary cultured cortical neurons. Neurosci Lett 288:163-166.

Schweers O, Mandelkow EM, Biernat J, Mandelkow E (1995) Oxidation of cysteine-322 in the repeat domain of microtubule-associated protein tau controls the in vitro assembly of paired helical filaments. Proc Natl Acad Sci USA 92:8463-8467.

Shumaker SA, Legault C, Rapp SR, Thal L, Wallace RB, Ockene JK, Hendrix SL, Jones III BN, Assaf AR, Jackson RD, Kotchen JM, Wassertheil-Smoller S, Wactawski-Wende J (2003) Estrogen plus progestin and the incidence of dementia and mild cognitive impairment in postmenopausal women: the Women's Health Initiative Memory Study: a randomized controlled trial. JAMA 289:2651-2662.

Shumaker SA, Legault C, Kuller L, Rapp SR, Thal L, Lane DS, Fillit H, Stefanick ML, Hendrix SL, Lewis CE, Masaki K, Coker LH (2004) Conjugated equine estrogens and incidence of probable dementia and mild cognitive impairment in postmenopausal women: Women's Health Initiative Memory Study. JAMA 291:2947-2958.

Simpkins JW, Singh M (2004) Consortium for the Assessment of Research on Progestins and Estrogens (CARPE) Fort Worth, Texas August 1-3, 2003. J Womens Health (Larchmt) 13:1165-1168.

Simpkins JW, Rajakumar G, Zhang YQ, Simpkins CE, Greenwald D, Yu CJ, Bodor N, Day AL (1997) Estrogens may reduce mortality and ischemic damage caused by middle cerebral artery occlusion in the female rat. J Neurosurg 87:724-730.

Singh M, Simpkins JW (2005) The future of estrogen and hormone therapy in postmenopausal women: what basic science and clinical studies teach us, Vol 1052. New York: New York Academy of Science.

Singh M, Setalo Jr G, Guan X, Warren M, Toran-Allerand CD (1999) Estrogen-induced activation of mitogen-activated protein kinase in cerebral cortical explants: convergence of estrogen and neurotrophin signaling pathways. J Neurosci 19:1179-1188.

Singh M, Setalo Jr G, Guan X, Frail DE, Toran-Allerand CD (2000) Estrogen-induced activation of the mitogen-activated protein kinase cascade in the cerebral cortex of estrogen receptor- $\alpha$ knock-out mice. J Neurosci 20:1694-1700.

Slevin M, Krupinski J, Slowik A, Rubio F, Szczudlik A, Gaffney J (2000) Activation of MAP kinase (ERK-1/ERK-2), tyrosine kinase and VEGF in the human brain following acute ischaemic stroke. NeuroReport 11:2759-2764.

Sontag E, Luangpirom A, Hladik C, Mudrak I, Ogris E, Speciale S, White CL, 3rd (2004) Altered expression levels of the protein phosphatase 2A ABalphaC enzyme are associated with Alzheimer disease pathology. J Neuropathol Exp Neurol 63:287-301.

Sortino MA, Chisari M, Merlo S, Vancheri C, Caruso M, Nicoletti F, Canonico PL, Copani A (2004) Glia mediates the neuroprotective action of estradiol on beta-amyloid-induced neuronal death. Endocrinology 145:5080-5086.

Stanciu M, Wang Y, Kentor R, Burke N, Watkins S, Kress G, Reynolds I, Klann E, Angiolieri MR, Johnson JW, DeFranco DB (2000) Persistent activation of ERK contributes to glutamate-induced oxidative toxicity in a neu- ronal cell line and primary cortical neuron cultures. J Biol Chem 275:12200-12206.

Sudo S, Wen TC, Desaki J, Matsuda S, Tanaka J, Arai T, Maeda N, Sakanaka M (1997) Beta-estradiol protects hippocampal CA1 neurons against transient forebrain ischemia in gerbil. Neurosci Res 29:345-354.

Takao T, Flint N, Lee L, Ying X, Merrill J, Chandross KJ (2004) 17betaEstradiol protects oligodendrocytes from cytotoxicity induced cell death. J Neurochem 89:660-673.

Tang MX, Jacobs D, Stern Y, Marder K, Schofield P, Gurland B, Andrews H, Mayeux R (1996) Effect of oestrogen during menopause on risk and age at onset of Alzheimer's disease. Lancet 348:429-432.

Wang X, Wang H, Xu L, Rozanski DJ, Sugawara T, Chan PH, Trzaskos JM, Feuerstein GZ (2003) Significant neuroprotection against ischemic brain injury by inhibition of the MEK1 protein kinase in mice: exploration of potential mechanism associated with apoptosis. J Pharmacol Exp Ther 304:172-178.

Wang ZQ, Chen XC, Yang GY, Zhou LF (2004) U0126 prevents ERK pathway phosphorylation and interleukin-1beta mRNA production after cerebral ischemia. Chin Med Sci J 19:270-275.

Watters JJ, Campbell JS, Cunningham MJ, Krebs EG, Dorsa DM (1997) Rapid membrane effects of steroids in neuroblastoma cells: effects of estrogen on mitogen activated protein kinase signalling cascade and c-fos immediate early gene transcription. Endocrinology 138:4030-4033.

Wynne RD, Saldanha CJ (2004) Glial aromatization decreases neural injury in the zebra finch (Taeniopygia guttata): influence on apoptosis. J Neuroendocrinol 16:676-683.

Wen Y, Yang S, Liu R, Brun-Zinkernagel AM, Koulen P, Simpkins JW (2004) Transient cerebral ischemia induces aberrant neuronal cell cycle re-entry and Alzheimer's disease-like tauopathy in female rats. J Biol Chem 279:22684-22692.

Wise PM, Dubal DB, Wilson ME, Rau SW, Liu Y (2001) Estrogens: trophic and protective factors in the adult brain. Front Neuroendocrinol 22:33-66.

Yang SH, He Z, Wu SS, He YJ, Cutright J, Millard WJ, Day AL, Simpkins JW (2001) 17-beta Estradiol can reduce secondary ischemic damage and mortality of subarachnoid hemorrhage. J Cereb Blood Flow Metab 21:174-181.

Zandi PP, Carlson MC, Plassman BL, Welsh-Bohmer KA, Mayer LS, Steffens DC, Breitner JC (2002) Hormone replacement therapy and incidence of Alzheimer disease in older women: the Cache County Study. JAMA 288:2123-2129.

Zhang L, Rubinow DR, Xaing G, Li BS, Chang YH, Maric D, Barker JL, Ma W (2001) Estrogen protects against beta-amyloid-induced neurotoxicity in rat hippocampal neurons by activation of Akt. NeuroReport 12:1919-1923.

Zhu JH, Kulich SM, Oury TD, Chu CT (2002a) Cytoplasmic aggregates of phosphorylated extracellular signal-regulated protein kinases in Lewy body diseases. Am J Pathol 161:2087-2098.

Zhu X, Lee HG, Raina AK, Perry G, Smith MA (2002b) The role of mitogenactivated protein kinase pathways in Alzheimer's disease. Neurosignals 11:270-281. 